University of Nebraska - Lincoln

DigitalCommons@University of Nebraska - Lincoln

Faculty Papers and Publications in Animal

Science

Animal Science Department

1998

\title{
Effect of Wet Corn Gluten Feed, Supplemental Protein, and Tallow on Steer Finishing Performance
}

\author{
C. J. Richards \\ University of Nebraska-Lincoln, Chris.Richards@okstate.edu \\ Rick Stock \\ University of Nebraska-Lincoln, rstock3@Unl.edu \\ Terry J. Klopfenstein \\ University of Nebraska-Lincoln, tklopfenstein1@unl.edu \\ D. H. Shain \\ University of Nebraska-Lincoln
}

Follow this and additional works at: https://digitalcommons.unl.edu/animalscifacpub

Part of the Animal Sciences Commons

Richards, C. J.; Stock, Rick; Klopfenstein, Terry J.; and Shain, D. H., "Effect of Wet Corn Gluten Feed, Supplemental Protein, and Tallow on Steer Finishing Performance" (1998). Faculty Papers and Publications in Animal Science. 520.

https://digitalcommons.unl.edu/animalscifacpub/520

This Article is brought to you for free and open access by the Animal Science Department at DigitalCommons@University of Nebraska - Lincoln. It has been accepted for inclusion in Faculty Papers and Publications in Animal Science by an authorized administrator of DigitalCommons@University of Nebraska - Lincoln. 


\title{
Effect of Wet Corn Gluten Feed, Supplemental Protein, and Tallow on Steer Finishing Performance ${ }^{1}$
}

\author{
C. J. Richards, R. A. Stock², T. J. Klopfenstein 3 , and D. H. Shain
}

Department of Animal Science, University of Nebraska, Lincoln 68583-0908

\begin{abstract}
Two trials evaluated the effects of level of wet corn gluten feed (WCGF), type of supplemental protein, and supplemental tallow on steer finishing performance. In Trial 1, WCGF was fed at 0,25 (two diets), or $50 \%$ of the dietary DM replacing dry-rolled corn (DRC), molasses, and a portion of the supplement. The DRC control diet and one $25 \%$ WCGF diet were supplemented with a combination of protein sources. The second $25 \%$ WCGF diet was supplemented with urea alone. The $50 \%$ WCGF diet contained no additional protein supplementation. No differences in DMI $(P>.10)$ were observed. Calves fed $25 \%$ WCGF plus a combina-
\end{abstract}

tion of protein sources or $50 \%$ WCGF gained faster ( $P$ $<.10)$ and more efficiently $(P<.10)$ than calves fed the DRC control. Calves fed $25 \%$ WCGF plus urea gained faster $(P<.10)$ and tended $(P=.14)$ to be more efficient than calves fed the DRC control. In Trial 2, WCGF was fed to replace 0 or $50 \%$ of the DRC and the molasses-urea supplement (DM basis). Both diets were fed with or without 3\% tallow. Steers fed WCGF gained faster $(P<.01)$ and more efficiently ( $P$ $<.01)$ than steers fed DRC. Inclusion of 3\% tallow increased gain $(P<.05)$ and improved efficiency $(P<$ $.05)$. Feed efficiency is improved by the addition of WCGF or tallow to DRC finishing diets.

Key Words: Protein, Gluten Feed, Tallow, Maize, Cattle

(01998 American Society of Animal Science. All rights reserved.

J. Anim. Sci. 1998. 76:421-428

\section{Introduction}

Wet corn gluten feed ( WCGF) contains 90 to $100 \%$ of the relative energy value of dry-rolled corn (DRC) in finishing diets ( $\mathrm{H}$ am et al., 1995). Less starch and more highly digestible fiber is associated with WCGF than with corn grain (DeH aan, 1983) and may reduce problems associated with acidosis (Firkins et al., 1985). Ruminal escape protein concentration is lower in WCGF than in corn (McCoy, 1996), and this may create a deficiency in metabolizable protein, especially for young, rapidly gaining calves fed finishing diets.

Wet distillers grains improved feed efficiency of cattle fed dry-rolled corn finishing diets from 2 to $17 \%$ when fed at levels of 5.2 to $40 \%$ of the dietary DM (Larson et al., 1993). Wet corn distillers grains contain $30 \%$ CP (47\% escape protein; Firkins et al., 1984) and approximately twice the lipid content found in corn or WCGF. Additional lipid content may explain a portion of the higher energy value (Larson et al.,

\footnotetext{
${ }^{1}$ Published with the approval of the director as paper no. 11833, journal ser., Nebraska Agric. Res. Div.

2Present address: Cargill, Inc., Blair, NE.

${ }^{3}$ To whom correspondence should be addressed.

Received February 26, 1997.

Accepted September 21, 1997.
}

1993) of wet distillers by-products compared with the energy value of WCGF (Ham et al., 1995).

The objectives of these trials were to determine the effects of level of WCGF in the diet, the interaction of level of WCGF and type of supplemental protein (urea or a combination of protein sources), and the interaction of level of WCGF and supplemental tallow on steer finishing performance.

\section{Materials and Methods}

Trial 1. British crossbred steer calves ( $n=160 ; 8$ to 9 mo of age; mean BW $276 \pm 19 \mathrm{~kg}$ ) were blocked by weight and allotted randomly within block to one of four treatments (four pens per treatment). Wet corn gluten feed (Cargill Corn Milling, Eddyville, I A) was fed at 0, 25 (two treatments), or $50 \%$ of the dietary DM replacing dry-rolled corn (DRC) and molasses. The DRC control diet and one 25\% WCGF diet were supplemented with a combination of urea $(50 \%$ of supplemental protein), soybean meal ( $25 \%$ of supplemental protein), and an 80:20 combination (DM basis) of feather meal and blood meal (25\% of supplemental protein). This combination of protein sources was formulated to supply N, amino acids, and peptides for microbial synthesis and escape protein in an attempt to meet metabolizable protein (MP) 
needs. A second $25 \%$ WCGF treatment was supplemented with urea (100\% of supplemental protein). The 50\% WCGF diet received no additional supplemental protein. Final finishing diets (Table 1) were formulated (DM basis) to contain a minimum of $13 \% \mathrm{CP}, .70 \% \mathrm{Ca}, .30 \% \mathrm{P}, .65 \% \mathrm{~K}$, and included 28 $\mathrm{mg} / \mathrm{kg}$ monensin (Elanco Animal Health, Indianapolis, IN), $11 \mathrm{mg} / \mathrm{kg}$ tylosin (Elanco Animal Health), and $53 \mathrm{mg} / \mathrm{kg}$ of thiamine (WCGF diets only). Nitrogen analysis of feed ingredients was performed using a combustion-type $\mathrm{N}$ analyzer (Perkin Elmer model PE 2410 Series II, Norwalk, CT). Actual dietary CP values (Table 1) were lower than calculated at the initiation of the trial due to lower than expected CP contents of DRC and WCGF.

Steers were implanted with Revalor (HoeschstRoussel Agri-Vet Company, Somerville, NJ ) initially and on d 92. Initial weights were the average of two consecutive days' weights taken before feeding. To minimize gut fill differences, all steers were fed a common diet (45\% alfalfa hay, 26\% WCGF , 23\% DRC,
3\% molasses, and 3\% supplement, DM basis) at an estimated $2 \%$ of their body weight (DM basis). All steers were adapted to their final diet in $21 \mathrm{~d}$ by feeding $45,35,25$, and $15 \%$ forage diets for $4,3,7$, and $7 \mathrm{~d}$, respectively, assuming alfalfa hay contained $100 \%$ forage and corn silage contained $50 \%$ forage. In the WCGF treatments, WCGF was added to the maximum treatment level ( 25 or $50 \%$, DM basis) before DRC increases began. The trial began November 30, 1993, and steers were fed for an average of $160 \mathrm{~d}$ in outside, dirt-mounded pens. At slaughter, hot carcass weights and liver scores were recorded. Liver scores were recorded in accordance with the system of Elanco Products Company (1974). Final weights were calculated from hot carcass weights assuming a constant $62 \%$ dressing percentage. After a 48-h chill, 12th rib fat thickness, quality grade, and yield grade were determined.

Net energy for gain for each diet was calculated according to procedures of Larson et al. (1993) with the exception that net energy required for daily gain

Table 1. Composition of finishing diets fed to calves in Trial 1

\begin{tabular}{|c|c|c|c|c|}
\hline \multirow[b]{2}{*}{ Item ${ }^{b}$} & \multicolumn{4}{|c|}{ Treatment $^{a}$} \\
\hline & DRC & $\begin{array}{c}25 \% \text { WCGF } \\
\text { + urea }\end{array}$ & $\begin{array}{l}25 \% \text { WCGF } \\
+ \text { protein }\end{array}$ & $50 \%$ WCGF \\
\hline Dry rolled corn & 78.30 & 61.00 & 61.00 & 36.00 \\
\hline Molasses $^{c}$ & 6.10 & - & - & - \\
\hline WCGF & - & 25.00 & 25.00 & 50.00 \\
\hline Corn silage & 5.00 & 5.00 & 5.00 & 5.00 \\
\hline Alfalfa hay & 5.00 & 5.00 & 5.00 & 5.00 \\
\hline \multicolumn{5}{|l|}{ Dry supplement } \\
\hline Finely ground corn & .09 & 1.89 & 1.54 & 1.83 \\
\hline Soybean meal & 1.86 & - & .28 & - \\
\hline Blood meal & .20 & - & .03 & - \\
\hline Feather meal & .80 & - & .12 & - \\
\hline Urea & .63 & .18 & .10 & - \\
\hline Limestone & 1.46 & 1.47 & 1.47 & 1.71 \\
\hline Sodium chloride & .21 & .30 & .30 & .30 \\
\hline Potassium chloride & .17 & - & - & - \\
\hline Tallow & .11 & .08 & .08 & .08 \\
\hline Vitamin premix ${ }^{d}$ & .01 & .01 & .01 & .01 \\
\hline Trace mineral premix & .03 & .03 & .03 & .03 \\
\hline Rumensin premix ${ }^{f}$ & .02 & .02 & .02 & .02 \\
\hline Tylan premix $x^{9}$ & .01 & .01 & .01 & .01 \\
\hline Thiamin premix ${ }^{h}$ & - & .01 & .01 & .01 \\
\hline \multicolumn{5}{|l|}{ Nutrient compositioni, \% } \\
\hline Crude protein & 11.62 & 11.25 & 11.27 & 13.22 \\
\hline Calcium & .70 & .70 & .70 & .83 \\
\hline Phosphorus & .32 & .49 & .50 & .69 \\
\hline Potassium & .65 & .65 & .66 & .89 \\
\hline
\end{tabular}

${ }^{a}$ DRC $=$ dry-rolled corn; WCGF = wet corn gluten feed; protein ( $\%$ of supplemental protein) $=50 \%$ urea, $25 \%$ soybean meal, and $25 \%$ of an $80: 20$ combination of feather meal and blood meal.

$\mathrm{b} b \%$ DM basis.

cMolasses contained $1.5 \% \mathrm{NaCl}$.

$\mathrm{d}_{15,000} \mathrm{IU}$ of vitamin A, 3,000 IU of vitamin D, and $3.75 \mathrm{IU}$ of vitamin $\mathrm{E} / \mathrm{g}$ of premix.

e $10 \% \mathrm{Mg}, 6 \% \mathrm{Zn}, 4.5 \% \mathrm{Fe}, 2 \% \mathrm{Mn}, .5 \% \mathrm{Cu}, .3 \% \mathrm{I}$, and $.05 \% \mathrm{Co}$.

${ }^{f} 132 \mathrm{~g}$ of monensin/kg of premix.

$988 \mathrm{~g}$ of tylosin/kg of premix.

$\mathrm{h} 88 \mathrm{~g}$ of thiamin $/ \mathrm{kg}$ of premix.

'CP based on measured values, other nutrients based on tabular values (NRC, 1984). 
Table 2. Feed ingredient nutrient values ${ }^{\mathrm{a}}$ used in NRC (1966) model calculations

\begin{tabular}{|c|c|c|c|c|c|c|c|c|}
\hline \multirow[b]{2}{*}{ Item } & \multicolumn{2}{|c|}{ Trial 1} & \multicolumn{2}{|c|}{ Trial 2} & \multirow[b]{2}{*}{$\mathrm{DIPC}$} & \multirow[b]{2}{*}{$\begin{array}{l}\text { Pretrial } \\
\text { TDN }^{d}\end{array}$} & \multirow[b]{2}{*}{ eNDF de } & \multirow[b]{2}{*}{$\mathrm{NDF}^{\mathrm{C}}$} \\
\hline & $\begin{array}{l}\text { Pretrial } \\
\text { CP }\end{array}$ & $\begin{array}{l}\text { Final } \\
\mathrm{CP} b\end{array}$ & $\begin{array}{c}\text { Pretrial } \\
\text { CP }\end{array}$ & $\begin{array}{l}\text { Final } \\
C P^{b}\end{array}$ & & & & \\
\hline Dry-rolled corn & 10.0 & 8.3 & 8.4 & 8.1 & 40 & 88 & 0 & 9.0 \\
\hline Wet corn gluten feed & 20.0 & 18.3 & 18.3 & 19.9 & 80 & 88 & 0 & 36.2 \\
\hline Molasses & 6.0 & 6.0 & - & - & 100 & 60 & 0 & 0 \\
\hline Molasses-urea supplement & - & - & 50.6 & 50.6 & 100 & 60 & 0 & 0 \\
\hline Corn silage & 8.0 & 7.3 & 8.0 & 5.0 & 75 & 75 & 71 & 41.0 \\
\hline Alfalfa hay & 15.9 & 14.2 & 15.0 & 5.0 & 80 & 52 & 92 & 53.0 \\
\hline Tallow & - & - & 0.0 & 0.0 & 0 & 0 & 0 & 0 \\
\hline Urea & 291.0 & 291.0 & 291.0 & 291.0 & 100 & 0 & 0 & 0 \\
\hline Soybean meal & 49.0 & 49.0 & - & - & 70 & 84 & 23 & 14.9 \\
\hline Blood meal & 90.0 & 90.0 & - & - & 20 & 66 & 0 & .9 \\
\hline Feather meal & 91.3 & 91.3 & - & - & 40 & 55 & 23 & 39.0 \\
\hline
\end{tabular}

apercentage (DM basis).

${ }^{b}$ Average crude protein content of dry-rolled corn, wet corn gluten feed, corn silage, and alfalfa hay samples determined in our laboratory. ${ }^{\mathrm{C} D I P}=$ degradable intake protein, assumed values for calculations.

dValues listed in NRC (1996) model except for dry-rolled corn, which was changed to 0\% eNDF and 9\% NDF.

eEffective NDF, percentage of NDF.

( $\mathbf{N E}_{\mathbf{g}} \mathbf{R}$ ) was calculated using the equation $\mathrm{NE}_{\mathrm{g}} \mathrm{R}=$ $.0493 \mathrm{~W}^{.75}$ (ADG ${ }^{1.097}$ ), where $\mathrm{NE}_{\mathrm{g}} \mathrm{R}$ ( $\mathrm{Mcal} / \mathrm{kg}$ gain) is the net energy required for daily weight gain (ADG, $\mathrm{kg} / \mathrm{d}$ ) and $\mathrm{W}(\mathrm{kg})$ is the mean body weight (NRC, 1984). All other calculations were the same as reported by Larson et al. (1993).

Degradable intake protein (DIP) and MP supplies and requirements were calculated using the NRC (1996) model and values in Table 2. The animal evaluated was a 422-kg, 12-mo-old Simmental-AngusHereford growing/finishing steer that had a body condition score of 5 and a mature weight of $568 \mathrm{~kg}$. Management settings included in the model were the use of an implant and ionophore. Environmental settings included the following values: $8 \mathrm{~km} / \mathrm{h}$ wind speed, previous and current temperatures of $0^{\circ} \mathrm{C}$, no night cooling, average hide thickness, some mud on the lower body, and no heat stress.
Assuming a DMI of $9.55 \mathrm{~kg} / \mathrm{d}$ and an ADG of 1.64 $\mathrm{kg} / \mathrm{d}$ before initiation of the trial, supplies of DIP and MP were calculated to exceed the animal's requirement (Table 3). Estimates of TDN and effective NDF ( NDF) on a DM basis and ruminal $\mathrm{pH}$ were also estimated.

After completion of the trial, degradable intake protein and MP supplies and requirements were estimated for each pen using the NRC (1996) model. Analyzed CP values for alfalfa, corn silage, corn, and WCGF were used for calculations. Actual pen DMI were used to calculate intakes of individual ingre dients. Amounts of individual ingredients fed were entered into the NRC (1996) model. The $\mathrm{NE}_{m}$ and $\mathrm{NE}_{\mathrm{g}}$ adjusters were changed equally until the proper ADG for the pen was achieved. Next, TDN percentages of the diets were calculated from $\mathrm{NE}_{\mathrm{g}}$ using

Table 3. Pretrial protein, effective NDF, and $\mathrm{pH}$ estimates using the NRC (1996) model for Trial 1

\begin{tabular}{|c|c|c|c|c|}
\hline \multirow[b]{2}{*}{ Item ${ }^{b}$} & \multicolumn{4}{|c|}{ Treatment $^{a}$} \\
\hline & $\begin{aligned} & \text { DRC } \\
+ & \text { protein }\end{aligned}$ & $\begin{array}{c}25 \% \text { WCGF } \\
+ \text { urea }\end{array}$ & $\begin{array}{l}25 \% \text { WCCF } \\
+ \text { protein }\end{array}$ & $50 \%$ WCGF \\
\hline 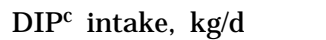 & .69 & .78 & .75 & 1.01 \\
\hline DIP requirement, $\mathrm{kg} / \mathrm{d}$ & .65 & .65 & .65 & .65 \\
\hline MPd supplied, $\mathrm{kg} / \mathrm{d}$ & .86 & .79 & .80 & .76 \\
\hline MP requirement $\mathrm{kg} / \mathrm{d}$ & .77 & .77 & .77 & .77 \\
\hline TDN, \% & 81 & 82 & 82 & 82 \\
\hline eNDFe, \% & 4.1 & 3.9 & 3.9 & 4.0 \\
\hline $\mathrm{pH}$ & 5.60 & 5.60 & 5.60 & 5.60 \\
\hline
\end{tabular}


formulas from NRC (1984). In the model, a dietary ingredient's TDN percentage was altered until the diet balanced for the TDN calculated from $\mathrm{NE}_{\mathrm{g}}$. Calculated TDN values were $82 \%$ for the DRC treatment and $84 \%$ (DM basis) for the remaining treatments. After obtaining the proper dietary TDN, ruminal $\mathrm{pH}$ was estimated. For diets containing WCGF, the eNDF value of WCGF in the model was adjusted to result in a ruminal $\mathrm{pH}$ increase of .09 and .18 units for the 25 and $50 \%$ WCGF diets, respectively. The adjustment of eNDF increasing ruminal $\mathrm{pH}$ in the model represented the average increase in ruminal $\mathrm{pH}$ observed by $\mathrm{Ham}$ et al. (1994) and Richards (1996) when feeding similar diets.

Statistical analysis was performed in accordance with procedures of Steel and Torrie (1980) for a randomized complete block design. Means were separated with Duncan's Multiple Range Test (alpha = .10) using the GLM procedure of SAS (1989). Pen was the experimental unit and the model effects included treatment and block.

Trial 2. Yearling steers ( $n=160$; mean $B W=346 \pm$ 45) were limit-fed $6.8 \mathrm{~kg}$ (DM basis) of a $50 \%$ corn silage and $50 \%$ alfalfa hay diet (DM basis) for $5 \mathrm{~d}$. Initial weights were taken on two consecutive days before feeding. Steers were blocked by weight (four pens per treatment) and allotted randomly within block to one of four treatments (10 steers/pen, four pens/treatment) in a $2 \times 2$ factorial arrangement of treatments. Wet corn gluten feed was fed to replace 0 or $50 \%$ of the DRC and molasses-urea supplement (DM basis). All diets were fed with or without the addition of $3 \%$ tallow (DM basis).

Final finishing diets (Table 4) were formulated (DM basis) to contain a minimum of $13 \% \mathrm{CP}, .70 \%$ $\mathrm{Ca}, .30 \% \mathrm{P}, .65 \% \mathrm{~K}$, and included $33 \mathrm{mg} / \mathrm{kg}$ monensin and $11 \mathrm{mg} / \mathrm{kg}$ tylosin. Diets containing WCGF had 53 $\mathrm{mg} / \mathrm{kg}$ thiamine added. Actual CP values were determined for feedstuffs as in Trial 1 . The CP concentration of DRC was lower during the trial than formulated and resulted in lower CP concentrations than calculated in the DRC diets. Lipid content of WCGF and DRC were measured using the chloroformmethanol extraction procedures of Moore et al. (1986).

Table 4. Composition of finishing diets fed to steers in Trial 2

\begin{tabular}{|c|c|c|c|c|}
\hline \multirow[b]{2}{*}{ Item $^{b}$} & \multicolumn{4}{|c|}{ Treatment $^{a}$} \\
\hline & DRC & $\begin{aligned} & \text { DRC } \\
+ & \text { tallow }\end{aligned}$ & $\begin{array}{l}50 \% \text { DRC: } \\
50 \% \text { WCGF }\end{array}$ & $\begin{array}{l}50 \% \text { DRC: } \\
50 \% \text { WCGF } \\
+ \text { tallow }\end{array}$ \\
\hline Dry-rolled corn & 82.00 & 78.90 & 44.01 & 42.43 \\
\hline WCGF & - & - & 44.00 & 42.43 \\
\hline Molasses-urea supplement ${ }^{c}$ & 5.00 & 5.00 & - & - \\
\hline Corn silage & 5.00 & 5.00 & 5.00 & 5.00 \\
\hline Alfalfa hay & 5.00 & 5.00 & 5.00 & 5.00 \\
\hline Tallow & - & 3.00 & - & 3.00 \\
\hline \multicolumn{5}{|l|}{ Dry supplement } \\
\hline Urea & .88 & .97 & .06 & .20 \\
\hline Limestone & 1.45 & 1.44 & 1.49 & 1.50 \\
\hline Sodium chloride & .30 & .30 & .30 & .30 \\
\hline Potassium chloride & .25 & .27 & - & - \\
\hline Tallow & .09 & .09 & .06 & .06 \\
\hline Vitamin premix ${ }^{d}$ & - & - & .01 & .01 \\
\hline Trace mineral premix ${ }^{e}$ & - & - & .03 & .03 \\
\hline Rumensin premix ${ }^{f}$ & .02 & .02 & .02 & .02 \\
\hline Tylan premix ${ }^{g}$ & .01 & .01 & .01 & .01 \\
\hline Thiamin premix ${ }^{h}$ & - & - & .01 & .01 \\
\hline \multicolumn{5}{|l|}{ Nutrient composition', \% } \\
\hline Crude protein & 12.71 & 12.72 & 15.94 & 15.51 \\
\hline Calcium & .70 & .70 & .70 & .70 \\
\hline Phosphorus & .30 & .30 & .52 & .51 \\
\hline Potassium & .65 & .65 & .94 & .91 \\
\hline \multicolumn{5}{|c|}{$\begin{array}{l}\text { aDRC = dry-rolled corn; WCGF = wet corn gluten feed. } \\
\text { bo\% DM basis. }\end{array}$} \\
\hline \multicolumn{5}{|c|}{$\begin{array}{l}\mathrm{d} 15,000 \mathrm{IU} \text { of vitamin } \mathrm{A}, 3,000 \mathrm{IU} \text { of vitamin } \mathrm{D} \text {, and } 3.75 \mathrm{IU} \text { of vitamin } \mathrm{E} / \mathrm{g} \text { of premix. } \\
\mathrm{e} 10 \% \mathrm{Mg}, 6 \% \mathrm{Zn}, 4.5 \% \mathrm{Fe}, 2 \% \mathrm{Mn}, .5 \% \mathrm{Cu}, .3 \% \mathrm{I} \text {, and } .05 \% \mathrm{Co} \text {. } \\
{ }^{176} \mathrm{~g} \text { of monensin/kg of premix. }\end{array}$} \\
\hline
\end{tabular}


Table 5. Pretrial protein, effective NDF, and $\mathrm{pH}$ estimates using the NRC (1996) model for Trial 2

\begin{tabular}{lcccc}
\hline \hline & \multicolumn{4}{c}{ Treatment $^{\mathrm{a}}$} \\
\cline { 2 - 5 } Item $^{\mathrm{b}}$ & DRC & $\begin{array}{c}\text { DRC } \\
\text { + tallow }\end{array}$ & $50 \%$ WCGF & $\begin{array}{c}50 \% \text { WCGF } \\
+ \text { tallow }\end{array}$ \\
\hline DIPC intake, kg/d $^{\text {D }}$ & .95 & .97 & .98 & .99 \\
DIP requirement, kg/d & .75 & .72 & .77 & .74 \\
MPd supplied, kg/d & .86 & .83 & .85 & .82 \\
MP requirement kg/d & .77 & .77 & .77 & .77 \\
TDN, \% & 82 & 79 & 84 & 81 \\
eNDFe, \% & 3.9 & 3.9 & 3.9 & 3.9 \\
pH & 5.59 & 5.59 & 5.59 & 5.59 \\
\hline
\end{tabular}

${ }^{a} \mathrm{DRC}=$ dry rolled corn; WCGF = wet corn gluten feed.

bDM basis; $10.91 \mathrm{~kg} / \mathrm{d}$ DMI; $1.64 \mathrm{~kg} / \mathrm{d}$ ADG.

${ }^{\mathrm{C}} \mathrm{DIP}=$ degradable intake protein.

$\mathrm{d}_{M P}=$ metabolizable protein .

eNDF = effective NDF

All steers were adapted to final diets in $21 \mathrm{~d}$ by feeding 45, 35, 25, and $15 \%$ forage diets for 2, 5, 7, and $7 \mathrm{~d}$, respectively. Concentrate increases in the 50\%DRC:50\% WCGF treatment during the adaptation period were increased in equal portions on a DM basis. Cattle were implanted with Revalor on $\mathrm{d} 1$ and the lightest replication received a second implant on $\mathrm{d} 78$. The trial began December 21, 1994, and steer replicates were fed for 93, 107, 135, and $149 \mathrm{~d}$.

Collection of hot carcass weights, liver scores, 12th rib fat thickness, quality grade, yield grade, and calculation of final weights were performed as in Trial 1. Net energy for gain for each diet was calculated as described in Trial 1 except $\mathrm{NE}_{\mathrm{g}} \mathrm{R}$ was calculated as $\mathrm{NE}_{\mathrm{g}} \mathrm{R}=.0557 \mathrm{~W} \cdot 75$ (ADG ${ }^{1.097}$ ).

Assuming a DMI of $10.91 \mathrm{~kg} / \mathrm{d}$ and an ADG of 1.64 $\mathrm{kg} / \mathrm{d}$ before initiation of the trial, protein supplies and requirements were calculated as in Trial 1. These calculations estimated the supply of DIP and MP to exceed requirements (Table 5). Estimates of TDN and eNDF on a DM basis and ruminal pH were also made.

After completion of the trial, protein supplies and requirements were calculated using the NRC (1996) model as in the previous trial with protein levels of feedstuffs, dietary TDN, average age of the animal (15 $\mathrm{mo})$, and average weight of the animal (445 kg) changed. Dietary TDN values calculated from $\mathrm{NE}_{\mathrm{g}}$ were $77,80,84$, and $88 \%$ (DM basis) for the DRC, DRC + tallow, 50\% WCGF, and 50\% WCGF + tallow, respectively.

Analysis of variance was according to procedures of Steel and Torrie (1980) for a randomized complete block with a $2 \times 2$ factorial arrangement of treatments. The GLM procedure of SAS (1989) was used

Table 6. Effect of wet corn gluten feed and supplemental protein on calf finishing performance in Trial 1

\begin{tabular}{|c|c|c|c|c|c|}
\hline \multirow[b]{2}{*}{ Item } & \multicolumn{5}{|c|}{ Treatment $^{\mathrm{a}}$} \\
\hline & $\begin{aligned} & \text { DRC } \\
+ & \text { protein }\end{aligned}$ & $\begin{array}{c}25 \% \text { WCGF } \\
\text { + urea }\end{array}$ & $\begin{array}{l}25 \% \text { WCCF } \\
\text { + protein }\end{array}$ & $50 \%$ WCGF & SEM \\
\hline DMI, kg/d & 9.60 & 9.90 & 10.09 & 9.81 & .19 \\
\hline Daily gain, kg & $1.71^{b}$ & $1.82^{c}$ & $1.88^{\mathrm{C}}$ & $1.84^{\mathrm{C}}$ & .03 \\
\hline Gain/feed & $.179^{b}$ & $.184^{\mathrm{bc}}$ & $.186^{\mathrm{C}}$ & $.187^{\mathrm{C}}$ & .002 \\
\hline DIP intake ${ }^{d}, k g / d$ & $.64^{a}$ & $.70^{\mathrm{b}}$ & $.70^{\mathrm{b}}$ & $.92^{c}$ & .16 \\
\hline DIP requirement, $\mathrm{kg} / \mathrm{d}$ & $.66^{\mathrm{a}}$ & $.77^{\mathrm{b}}$ & $.77^{\mathrm{b}}$ & $.79^{b}$ & .14 \\
\hline MP suppliede, kg/d & .83 & .82 & .86 & .82 & .15 \\
\hline Fat thickness, $\mathrm{cm}$ & $.89^{b}$ & $.97^{\mathrm{b}}$ & $1.09^{c}$ & $1.09^{c}$ & .05 \\
\hline Quality grade ${ }^{f}$ & 18.6 & 18.3 & 18.4 & 18.3 & .2 \\
\hline $\mathrm{NE}_{\mathrm{g}}$ diet, $\mathrm{Mcal} / \mathrm{kg}^{\mathrm{g}}$ & $1.34^{\mathrm{a}}$ & $1.39^{\mathrm{ab}}$ & $1.41^{b}$ & $1.41^{\mathrm{b}}$ & .02 \\
\hline \multicolumn{6}{|c|}{$\begin{array}{l}\text { aDRC = dry-rolled corn; WCGF = wet corn gluten feed; protein ( } \% \text { of supplemental protein) }=50 \% \\
\text { urea, } 25 \% \text { soybean meal, and } 25 \% \text { of a } 80: 20 \text { combination of feather meal and blood meal. } \\
\text { b,cM eans within a row with unlike superscripts differ }(P<.10) \text {. } \\
\text { dDIP = degradable intake protein. } \\
\text { eMP = metabolizable protein; requirement }(\text { NRC, 1996) for average WCGF daily gain }(1.85 \mathrm{~kg} / \mathrm{d})=.83\end{array}$} \\
\hline
\end{tabular}


Table 7. Effect of wet corn gluten feed and tallow on finishing steer performance in Trial 2

\begin{tabular}{|c|c|c|c|c|c|}
\hline \multirow[b]{2}{*}{ Item } & \multicolumn{4}{|c|}{ Treatment $^{a}$} & \multirow[b]{2}{*}{ SEM } \\
\hline & DRC & $\begin{aligned} & \mathrm{DRC} \\
+ & \text { tallow }\end{aligned}$ & $\begin{array}{c}50 \% \text { DRC: } \\
50 \% \text { WCGF }\end{array}$ & $\begin{array}{c}50 \% \text { DRC: } \\
50 \% \text { WCGF } \\
+ \text { tallow }\end{array}$ & \\
\hline DMI, kg/d & 11.17 & 10.98 & 10.86 & 10.91 & .12 \\
\hline Daily gain ${ }^{b c}, k g$ & 1.56 & 1.64 & 1.71 & 1.80 & .03 \\
\hline Gain/feed bc & .142 & .151 & .159 & .166 & .008 \\
\hline DIP intake ${ }^{b d}, k g / d$ & .96 & .96 & 1.03 & 1.04 & .10 \\
\hline DIP required be, $\mathrm{kg} / \mathrm{d}$ & .72 & .75 & .89 & .93 & .10 \\
\hline MP supplied bf, $\mathrm{kg} / \mathrm{d}$ & .85 & .85 & .94 & .96 & .09 \\
\hline Fat thickness, cm & .97 & .94 & .91 & 1.02 & .05 \\
\hline Quality gradeg & 18.6 & 18.4 & 18.4 & 18.8 & .3 \\
\hline $\mathrm{NE}_{\mathrm{g}}$ diet, Mcal $/ \mathrm{kg}^{\text {beh }}$ & 1.23 & 1.30 & 1.39 & 1.44 & .02 \\
\hline \multicolumn{6}{|c|}{ 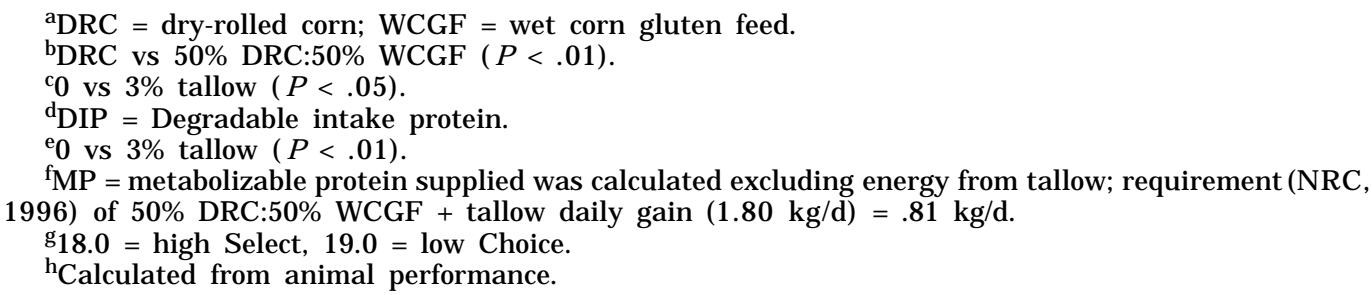 } \\
\hline
\end{tabular}

with model effects that included treatment and block. Preplanned contrasts of DRC vs $50 \%$ WCGF, 0 vs $3 \%$ tallow, and WCGF level $\times$ tallow level were used to separate treatment means.

\section{Results and Discussion}

Trial 1. Steers fed 25 or $50 \%$ WCGF gained faster $(\mathrm{P}<.10 ;$ Table 6$)$ than calves fed the DRC control, but no differences were observed $(P>.10)$ in DMI. Calves fed the $25 \%$ WCGF diet plus a combination of protein sources or $50 \%$ WCGF diet were more efficient $(\mathrm{P}<.10)$ than calves fed the DRC control. Calves fed $25 \%$ WCGF plus urea tended $(P=.14)$ to be more efficient than calves fed the DRC control. An increase in efficiency and gain may be attributed to a reduction of subacute acidosis (Stock et al., 1990). A reduction in subacute acidosis has been suggested by Farlin (1981) and Firkins et al. (1985) when corn byproducts were fed. The faster and more efficient gains of the calves on the WCGF diets resulted in increased $(\mathrm{P}<.10)$ fat over the 12 th rib, but quality grade, yield grade (data not shown), and liver scores (data not shown) were not affected.

Net energy for gain calculated from animal performance and NRC (1984) values for the DRC control diet were 1.34 vs $1.38 \mathrm{Mcal} / \mathrm{kg}$, respectively. Assuming a $\mathrm{NE}_{\mathrm{g}}$ of $1.55 \mathrm{Mcal} / \mathrm{kg}$ for DRC, energy values for WCGF were calculated to be $1.59,1.66$, and $1.62 \mathrm{Mcal} /$ $\mathrm{kg}$ for the $25 \%$ plus urea, $25 \%$ plus protein, and $50 \%$ WCGF treatments, respectively. The average WCGF energy value calculated from this trial $(1.62 \mathrm{M} \mathrm{cal} / \mathrm{kg})$ is higher than the values of 1.40 and $1.55 \mathrm{Mcal} / \mathrm{kg}$ found for WCGF diets in two finishing trials by Ham et al. (1995). In the two trials conducted by $\mathrm{Ham}$ et al. (1995), British crossbred yearling cattle were fed WCGF at 35 and $70 \%$ or $17.5,35,52.5,70$, and $87.5 \%$ of dietary DM. Two trials determining energy values for WCGF were conducted by Trenkle $(1986 a, b)$. When feeding heifers finishing diets containing 30 or $60 \%$ WCGF, the metabolizable energy value for WCGF was $22 \%$ lower than for DRC. In the second trial, an energy value of $9 \%$ less than DRC was calculated from steers fed finishing diets with 30,50 , and $70 \%$ of the DRC and corn silage replaced by WCGF.

Degradable intake protein was lowest for the DRC control, intermediate for 25\% WCGF treatment, and highest for the 50\% WCGF treatment $(P<.10)$. The DIP intakes of cattle consuming the DRC and $25 \%$ WCGF diets were estimated to be deficient. However, the additional $\mathrm{N}$ needs of these treatments may have been met by recycled urea in the animal. The model uses a constant rate of $\mathrm{N}$ recycling. Ruminants may have a greater ability to recycle $\mathrm{N}$ when it is limiting than is allowed for by the NRC (1996) model. When calculating DIP requirements and adjusting $\mathrm{pH}$ level using effective NDF, the DIP required will be altered and a requirement should be calculated for each diet. Strobel and Russell (1986) conducted in situ experiments that showed that mixed ruminal bacteria produced $50 \%$ less protein at $\mathrm{pH} 5.7$ than at $\mathrm{pH} 6.7$. Therefore, when effective NDF is less than $20 \%$ of the dietary DM, the microbial yield predicted is reduced $2.5 \%$ for every $1 \%$ decrease in effective NDF (Russell et al., 1992). If DIP becomes limiting, microbial CP yield should decline. Metabolizable protein requirement is driven by ADG for a given animal. All animals 
in a trial are assumed to be capable of equal rates of gain. Therefore, the requirement for MP should be based on the highest-gaining treatment or group of treatments. Because the WCGF treatment ADG were not different $(P>.10)$, the average ADG from the WCGF treatments $(1.85 \mathrm{~kg})$ was used for determining the MP requirement for this trial. Metabolizable protein supplied was not different $(P<.10)$ for any of the treatments, but the MP supplied was estimated to be slightly below the requirement for the $25 \%$ WCGF + urea and 50\% WCGF treatments.

In a finishing trial, Krehbiel et al. (1995) fed varying levels of WCGF to yearling Hereford steers with or without addition of escape protein. The addition of escape protein did not result in an increase in performance. In contrast, Trenkle (1992) reported an increased MP requirement when feeding DRCbased diets to large-framed yearling steers implanted with Synovex-S and Finaplix-S.

Trial 2. Steers fed $50 \%$ WCGF diets gained faster $(P<.01)$ and more efficiently $(P<.01)$ than steers fed DRC diets; DMI did not differ among treatments $(P>.10 ;$ Table 7$)$. Daily gains of steers were higher $(P<.05)$ and more efficient $(P<.05)$ when $3 \%$ tallow was included in the diets. No treatment effects were observed $(P>.10)$ for 12 th rib fat thickness, quality grade, liver score (data not shown), or yield grade (data not shown). No significant WCGF level $\times$ tallow level interaction ( $P>.10)$ was detected for any measure.

Net energy for gain estimated from dietary ingredients (1.38 M cal/kg; NRC, 1984) was higher than the value calculated from animal performance (1.23 M cal/ $\mathrm{kg}$ ) for the control diet. Greater precipitation over the feeding period may be responsible for reduced animal performance in this trial. Adding WCGF to the diet increased $\mathrm{NE}_{\mathrm{g}}(\mathrm{P}<.01)$, as did the addition of tallow $(P<.01)$. The $\mathrm{NE}_{\mathrm{g}}$ value of WCGF, when tallow was not fed, was calculated to be $1.91 \mathrm{Mcal} / \mathrm{kg}$, which is $23 \%$ greater than the $\mathrm{NE}_{\mathrm{g}}$ value of DRC $(1.55 \mathrm{Mcal} /$ $\mathrm{kg}$; NRC, 1984). The $\mathrm{NE}_{\mathrm{g}}$ value of tallow, when WCGF was not fed, was calculated to be $4.38 \mathrm{Mcal} / \mathrm{kg}$, which is similar to NRC (1996).

Intake of DIP exceeded the requirement for all treatments and was greater $(P<.01)$ for WCGF diets than for DRC diets. The requirement for DIP was increased $(P<.01)$ by the inclusion of WCGF. Increases in DIP requirements due to additions of WCGF were an extension of the $\mathrm{pH}$ adjustment in the model during the calculation of the requirement. The ADG from the $50 \%$ DRC:50\% WCGF + tallow treatment $(1.80 \mathrm{~kg} / \mathrm{d})$ was used to calculate the MP requirement. Metabolizable protein supplied increased with the addition of WCGF $(P<.01)$. The estimation of TDN from $\mathrm{NE}_{\mathrm{g}}$ may have overestimated the energy available for microbial growth because the energy from tallow is included but is not available for microbial growth. Nocek and Russell (1988) reported that ruminal bacteria only grow on ruminally degraded carbohydrates and do not use fats as an energy source. The inclusion of energy from tallow increases the DIP requirement and increases the estimate of MP due to a greater microbial growth.

The $\mathrm{NE}_{\mathrm{g}}$ value of the WCGF and tallow combination was $2.00 \mathrm{Mcal} / \mathrm{kg}$, which is $29 \%$ greater than DRC and approaches the energy value of distillers byproducts, as reported by Larson et al. (1993) and Ham et al. (1994). Higher production responses reported for wet distillers grains than for WCGF may be attributed to highly digestible fiber, lipid, or escape protein. Both products are fibrous by-products, but wet distillers grains have a higher lipid content (15 vs 9\%; Ham et al., 1995) and are higher in escape protein (47 vs $26 \%$, DM basis; Firkins et al., 1984). Lipid content of the WCGF and DRC in our trial was 5.6 and $5.3 \%$, respectively. The differences in lipid content and escape protein between WCGF and distillers by-products were evaluated by Lodge et al. (1997). In that trial, a composite of corn gluten feed, tallow, and corn gluten meal was fed. Wet corn gluten feed or the composite was fed as $40 \%$ (DM basis) of a DRC finishing diet. Steers consuming the composite were more efficient than steers consuming WCGF.

\section{Implications}

Wet corn gluten feed and distillers grains are fibrous by-products of grain processing. Wet corn gluten feed has been fed to replace dry-rolled corn in finishing cattle diets without causing a decrease in gains or efficiencies. A combination of tallow and wet corn gluten feed seems to further improve feed efficiency. Type of protein supplementation seems to be influenced by several animal and dietary factors that influence metabolizable protein and degradable intake protein supplies and requirements.

\section{Literature Cited}

DeHaan, K. A. 1983. Improving the utilization of fiber and energy through the use of corn gluten feed and alkali compounds. Ph.D. Dissertation. Univ. of Nebraska, Lincoln.

Elanco Products Company. 1974. Tylan premix for beef cattle. Technical B Manual. pp 4-5. Indianapolis, IN.

Farlin, S. D. 1981. Wet distillers grains for finishing cattle. Anim. Nutr. Health 36 (No. 3):35.

Firkins, J . L., L. L. Berger, and G. C. Fahey, J r. 1985. Evaluation of wet and dry distillers grains and wet and dry corn gluten feeds for ruminants. J. Anim. Sci. 60:847-860.

Firkins, J. L., L. L. Berger, G. C. Fahey, J r., and N. R. Merchen. 1984. Ruminal nitrogen degradability and escape of wet and dry distillers grains and wet and dry corn gluten feeds. J . Dairy Sci. 67:1936-1944.

Ham, G. A., R. A. Stock, T. J. Klopfenstein, and R. P. Huffman. 1995. Determining the net energy value of wet and dry corn gluten feed in beef growing and finishing diets. J . Anim. Sci. 73: 353-359.

Ham, G. A., R. A. Stock, T. J . Klopfenstein, E. M. Larson, D. H. Shain, and R. P. Huffman. 1994. Wet corn distillers byproducts compared with dried corn distillers grains with solubles as a source of protein and energy for ruminants. J. Anim. Sci. 72: 3246-3257. 
Krehbiel, C. R., R. A. Stock, D. W. Herold, D. H. Shain, G. A. Ham, and J. E. Carulla. 1995. Feeding wet corn gluten feed to reduce subacute acidosis in cattle. J. Anim. Sci. 73:2931-2939.

Larson, E. M., R. A. Stock, T. J . Klopfenstein, M. H. Sindt, and R. P. Huffman. 1993. Feeding value of wet distillers byproducts for finishing ruminants. J. Anim. Sci. 71:2228-2236.

Lodge, S. L., R. A. Stock, T. J . Klopfenstein, D. H. Shain, and D. W. Herold. 1997. Evaluation of wet distillers composite for finishing ruminants. J. Anim. Sci. 75:44-50.

McCoy, R. A. 1996. Receiving and finishing programs for calves. Ph.D. Dissertation. Univ. of Nebraska, Lincoln.

Moore, J . A., R. S. Swingle, and W. H. Hale. 1986. Effects of whole cottonseed, cottonseed oil or animal fat on digestibility of wheat straw diets by steers. J. Anim. Sci. 63:1267-1273.

Nocek, J. E., and J. B. Russell. 1988. Protein and energy as an integrated system. Relationship of ruminal protein and carbohydrate availability to microbial protein synthesis and milk production. J. Dairy Sci. 71:2070-2107.

NRC. 1984. Nutrient Requirements of Beef Cattle (6th Ed.). National Academy Press, Washington, DC.

NRC. 1996. Nutrient Requirements of Beef Cattle (7th Ed.). National Academy Press, Washington, DC.

Richards, C. J . 1996. Evaluation of grains and grain byproducts for ruminants. M.S. Thesis. Univ. of Nebraska, Lincoln.
Russell, J. B., J . D. O'Connor, D. G. Fox, P. J . Van Soest, and C. J . Sniffen. 1992. A net carbohydrate and protein system for evaluating cattle diets: I. Ruminal fermentation. J. Anim. Sci. 70: 3551-3561.

SAS. 1989. SAS User's Guide Statistics (6th Ed.). SAS Inst. Inc., Cary, NC.

Steel, R.G.D., and J. H. Torrie. 1980. Principles and Procedures of Statistics: A Biometrical Approach (2nd Ed.). McGraw-Hill Publishing Co., New York.

Stock, R. A., M. H. Sindt, J . C. Parrott, and F. K. Goedeken. 1990. Effects of grain type, roughage level and monensin level on finishing cattle performance. J. Anim. Sci. 68:3441-3455.

Strobel, H. J., and J. B. Russell. 1986. Effect of pH and energy spilling on bacterial protein synthesis by carbohydrate limited cultures of mixed rumen bacteria. J . Dairy Sci. 69:2941-2947.

Trenkle, A. 1986a. Comparison of wet and dry corn gluten feed when used to replace corn and corn silage in a ration for yearling steers. Iowa State Univ. Beef Cattle Res. Rep. RA402:23-28.

Trenkle, A. 1986b. Feeding value of wet and dry corn gluten feed when used to replace corn and corn silage in a ration for yearling heifers. I owa State Univ. Beef Cattle Res. Rep. RA401: 19-22.

Trenkle, A. 1992. Protein requirements of steers implanted with Synovex S and Finaplix S. I owa State Beef-Sheep Res. Rep. AS620:102-107. 